\title{
"COOPERATIVE FEDERALISM" AGAIN: STATE AND MUNICIPAL LEGISLATION PENALIZING VIOLATION OF EXISTING AND FUTURE FEDERAL REQUIREMENTS: II;
}

\author{
SAMUEL MERMIN'
}

\section{CONSTITUTIONAL RESTRICTIONS ON INCORPORATION BY REFERENCE}

One objection to state or municipal "incorporation by reference" of federal statutes or regulations has already been considered: that it constitutes an unconstitutional delegation of legislative power. Another objection is based on those state constitutional provisions which prescribe the form in which legislation is to be enacted. Thus, approximately two-thirds of the states have constitutional provisions to the general effect that no law shall be revived, revised, or amended by reference to its title only-it being required that so much as is revived, revised or amended be copied into the law being enacted. However, it is clear that a state adoptive law is neither "reviving," "revising," or "amending" the federal law which it adopts. Hence, this constitutional provision is usually held not to be a barrier to state laws incorporating other state or federal laws. ${ }^{1}$

In the constitutions of nine states there is added to the phrase "that no act may be revived, revised, or amended by reference to its title only," the words "or the provisions thereof extended or conferred." 2 This, too, is not apt language to cover the adoption situation, and no difficulty seems to have been encountered in these states ${ }^{3}$-with slight exception. A New Mexico court, reversing itself after rehearing, declared that the addition of the word "extended" was sufficient to render invalid an attempted state adoption of the provisions of the National

* The first part of this article appeared in 57 YALE L. J. 1 (1947).

$\div$ Professor of Law, University of Ollahoma Law School; formerly Solicitor, Litigation Division, Enforcement Department, OPA. The author has felt irce to draw on the briefs he prepared for the Price Administrator on some of the matters discussed herein.

1. E.g., State Docks Commission v. State, 227 Ala, 521, 150 So. 345 (1933); In re Altman, 26 Ariz. 635, 229 Pac. 388 (1924); Central of Georgia R. R. Co. v. State, 104 Ga. 831, 31 S.E. 531 (1S98); Boise City v. Baxter, 41 Idaho 368, 238 Pac. 1029 (1915); Lyman v. Ramey, $195 \mathrm{Ky} .223$, 242 S.W. 21 (1922); Spahn v. Stewart, 268 Ky. 97, 103 S.W.2d 651 (1937); State v. Dehart, 109 L3. 570, 574, 33 So. 605, 606 (1903); State v. Peyton, 234 M10. 517, 523, 137 S.W. 979, 980 (1911); State ex rel. Berthot v. High School District, 102 21ont. 356, 58 P.2d 264 (1936); Dept. of Banking v. Foe, 136 Neb. 422, 286 N.W. 264 (1939); Town of Haskell v. Edmonds, 90 Okla. 44, 215 Pac. 629 (1923); Hunt v. Tausick, 64 Wash. 69, 116 Pac. 651 (1911). But see Carroll v. Hartford Fire Insurance Co., 28 Idaho 465, 154 Pac. 985 (1916); Ex parte Mantell, 47 Nev. 95, 216 Pac. 509 (1923).

2. Ala., Ark., Colo., Ky., Míont., N.Mr., Okla., Pa., Wyo.

3. See the Alabama, Kentuchy and Oklahoma cases in note 1, sospro. 
Prohibition Act. ${ }^{4}$ In Pennsylvania, by contrast, an unfavorable dictum with respect to adoption of a definition in the federal food and drug law in a lower court case ${ }^{5}$ has probably been dissipated. ${ }^{6}$

The only remaining constitutional provisions which seem to present any problem are those in Louisiana, North Dakota, New Jersey and New York. The Louisiana Constitution provides that the legislature shall never adopt "any system or code of laws by general reference to such system or code of laws; but in all cases shall recite at length the several provisions of the laws it may enact." 7 The North Dakota Constitution states: "No bill shall be revised or amended, nor the provisions thereof extended or incorporated in any other bill by reference to its title only. . . ." 8 There are apparently no cases directly in point in either of these states, though some Louisiana decisions ${ }^{9}$ as well as some North Dakota decisions ${ }^{10}$ indicate a rather strict construction.

The New York Constitution, ${ }^{11}$ with which the New Jersey Constitution is virtually identical, ${ }^{12}$ is the strictest of all: "No act shall be passed which shall provide that any existing law, or any part thereof, shall be made or deemed a part of said act, or which shall enact that any existing law, or part thereof, shall be applicable except by inserting it in such act." A New Jersey lower court ${ }^{13}$ and the New York Court of Appeals in the Darweger case ${ }^{14}$ felt that this provision prevented incorporation of federal NRA codes, but other New Jersey cases $^{15}$ have permitted a

4. State v. Armstrong, 31 N.Mex. 220, 243 Pac. 333 (1924).

5. Commonwealth v. Dougherty, $39 \mathrm{~Pa}$. Super. 338 (1909).

6. Commonwealth v. Alderman, $275 \mathrm{~Pa} .483,119$ Atl. 551 (1924).

7. LA. Const. Art. $3, \S 18$.

8. N.D. Const. Art. $2, \S 64$.

9. State v. Dehart, 109 La. 570, 33 So. 605,607 (1903) ; Rathborne v. Coll. of Int. Rev., 196 La. 795, 200 So. 149, 154 (1941); of. State v. Cleary, 152 La. 265, 92 So. 892 (1922).

10. State ex rel. Gammons v. Shafer, 63 N.D. 128, 246 N.W. 874 (1933); Dept. of State Highways v. Baker, 69 N.D. 702, 290 N.W. 257 (1940).

11. N.Y. Const. Art. 3, \$16.

12. N.J. Const. Art. $4, \S 7$.

13. Wilentz v. Sears Roebuck, 12 N.J. Misc. 531, 17 Atl. 903 (Ch. 1934). There was an analogous lower court ruling with respect to incorporation of federal air regulations, New Jersey v. Larson, 10 N.J. Misc. 384 (Co. Ct. of Oyer \& Ter. 1932). Both cases also frowned on the delegation involved.

14. Darweger v. Staats, 267 N.Y. 290, 196 N.E. 61 (1935). Some previous courts in New York had agreed. Cline v. Consumers' Cooperative, 152 Misc. 653, 274 N.Y. Supp. 362 (1934) ; De Agostina v. Parkshire Ridge Amusements, 155 Misc. 518, 278 N.Y. Supp. 622 (1935). At least one had held otherwise. Spaulding v. Kaminski, 153 Misc. 678, 276 N.Y. Supp. 663 (1934) (codes are not "laws").

15. Texas Co. v. Dickinson, 79 N.J.L. 292, 75 Atl. 803 (Sup. Ct. 1910) (reciprocal tax statute) ; Hutches v. Borough of Hohokus, 82 N.J.L. 140, 81 Atl. 658 (Sup. Ct. 1911) (incorporating procedural provisions of existing state statutes); State v. Masnik, 123 N.J.L. 335, 8 A.2d 701, aff'd, 125 N.J.L. 34, 12 A.2d 871 (1940) (incorporating commonlaw of incest); Scharf v. Reiser, 91 Atl. 642 (N.J. Sup. 1914) (defining a phrase by 
variety of incorporations; and People \%. Mailman ${ }^{16}$ and other New York cases were able to cite respectable New York predecents for the incorporation by reference of OPA requirements. ${ }^{17}$ Whether on the one hand the Mailman decision is a result of the special nature of the Emergency Price Control Act or special feelings about the war, or on the other hand, the Darzeger case was the result of the special nature of the $\mathrm{Na}$ tional Industrial Recovery Act and strong feelings felt about that statute, is not clear. At any rate, in New York as well as in New Jersey, there are usable precedents that may result in sustaining future instances of incorporation of federal requirements. It should be noted, finally, that the constitutional limitations on incorporation by reference would not generally be regarded as applicable to municipal ordinances. ${ }^{18}$

\section{OCCupation of the Field: CONFLict OR INCONSISTENCY}

One of the major reasons for the Ohio Supreme Court's invalidation of the Cleveland ordinance, adopting and enforcing OPA regulations, was its belief that the Emergency Price Control Act occupied the field "upon a subject matter which is national in character and can be governed only by a uniform system, to wit, nation-wide rationing and

reference to another New Jersey statute) ; Bd. of Education of Newark v. Civil Service Commission of N. J., 98 N.J.L. 417, 119 Atl. 875 (Sup. Ct. 1923) (extending provisions of the state civil-service law to school-districts).

16. 293 N.Y. 887,59 N.E.2d 790 (1944), affirming 182 Afisc. 870, 49 N.Y.S.2d 733 (N.Y. City Cts. 1944).

17. The lower court in the Mailman case, aff'd without opinion, stressed the factor we have discussed previously in connection with delegation, namely that the federal requirements were already applicable to intrastate commerce in New York state (which had not been true in the Darweger case); the state law concerned the "mere enforcemcnt of existing federal laws already applicable" But, also cited was a case in which this factor was not present: Transit Commission v. Long Island R.R., 248 App. Div. 749, 288 N.Y. Supp. 938 (1936), aff'd 272 N.Y. 27 (1936) (certain intrastate rates made to vary with interstate rates controlled by I.C.C.). The Transit case had cited Wathinson v. Hotel Pennsylvania, 195 App. Div. 624, 187 N.Y. Supp. 278 (1921), aff'd, 231 N.Y. 562, 132 N.E. 889 (1921) (incorporating federal statutory conditions for grants-in-aid). Other New York cases upholding the incorporation of OPA regulations were Butter \& Egg Mrerchants Ass'n v. LaGuardia, 181 Misc. 8\$9, 47 N.Y.S.2d 913 (Sup. Ct. 1944) ; Mosner v. Haddock, 181 Misc. 486, 46 N.Y.S.2d 343 (Sup. Ct. 1944), af'd, 268 App. Div. 752, 48 N.Y.S.2d 802 (1944); People v. Brongofsky, 181 Mise. 782, 50 N.Y.S.2d 32 (N.Y. City Cts. 1943).

18. Since the constitutional provision that a "law" should contain one subject, es:pressed in its title, is generally held to apply only to state law (37 A3r. Jur. $\$ 146$ ) and since this occurs in the same sentence or section as the provision on amending, ete. by reference to title, the same rule should apply. It was specifically so held in Baumgartner v. Hasty, 100 Ind. 575, 50 Am. Rep. 830 (1884); City of Philadelphia v. Houlihan, 37 Pa. D.\&C. 29 (1940). Many cases have upheld reference ordinances without reierring to the constitutional provision. Sie, e.g., Sloss-Sheffield Steel Co. v. Smith, $175 \mathrm{Ala}$. 260, 57 So. 29 (1911); Casteel v. City of Decatur, 215 Ala. 4, 109 So. 571 (1926); Richards v. Town of Magnolia, 100 Miss. 249, 56 So. 386 (1911). 
price control of commodities and rents. Nowhere in the Act has Congress granted its express consent to the exercise of concurrent power by the states." 19 The Michigan Supreme Court, on the other hand, held that the Detroit OPA ordinance was not an "unconstitutional encroachment upon the war powers of the Congress", ${ }^{20}$ citing the state sedition acts during World War I, which had been upheld, ${ }^{21}$ and Section 201(a) of the Emergency Price Control Act, which authorized the Price Administrator to "utilize the services of Federal, State and local agencies. . . ." ${ }^{22}$ So, too, the lower court in the Mailman case, affirmed without opinion by the New York Court of Appeals, held that New York State had power to adopt its anti-inflationary measures assisting the national government in time of war, since they did not conflict with those of the national government; ${ }^{23}$ and the Puerto Rico Supreme Court ruled similarly with respect to the Puerto Rico law. ${ }^{24}$ Whether, in the case of future examples of adoptive legislation, the "occupation of the field" obstacle will be interposed is not easily answered. Considerable confusion has resulted from the application of this doctrine, and it has often been said that no formula exists for its ready application. ${ }^{25}$ Sometimes state requirements going beyond those which Congress has provided in a particular field will be permitted, ${ }^{20}$ yet sometimes completely identical or harmonious regulation will not be, on the theory that "when Congress has taken the particular subject matter in hand, coincidence is as ineffective as opposition." ${ }^{27}$ Significance may be attached to a provision by Congress merely authorizing federal cooperation with state and local bodies. ${ }^{28} \mathrm{~A}$ federal adminis-

19. City of 'Cleveland v. Piskura, 145 Ohio St. 144, 153, 60 N.E.2d 919, 923 (1945).

20. People v. Sell, 310 Mich. 305, 328, 17 N.W.2d 193, 201 (1945).

21. Gilbert v. Minnesota, 254 U.S. 325 (1920), State v. Holm, 139 Minn. 267, 166 N.W. 181 (1918).

22. 56 StAT. 29 , 50 U.S.C. App. $\$ 921$ (1942).

23. People v. Mailman, 182 Misc. $870,878,49$ N.Y.S.2d 733, 739 (N.Y. City Cts. 1944).

24. Irizarry v. District Court of Ponce, 2 Pike AND Fischer 2196, 2197-8 (Sup. Ct., Puerto Rico, 1944). The court also referred to Puerto Rico v. Shell, 302 U.S. 253 (1937) which had sustained a Puerto Rico anti-trust statute making prohibitions substantially similar to those of the federal anti-trust law which was also applicable in Puerto Rico.

25. See Welch v. New Hampshire, 306 U.S. 79, 84 (1939).

26. See, e.g., Savage v. Jones, 225 U.S. 501 (1912) ; Kelly v. Washington, 302 U.S. 1 (1937) ; Mintz v. Baldwin, 289 U.S. 346 (1933); Maurer v. Hamilton, 309 U.S. 598 (1940); Dickson v. Uhlmann Grain Co., 288 U.S. 188 (1933).

27. Charleston \& W. C. Ry. v. Varnville Furn. Co., 237 U.S. 597, 604 (1915). Sec Southern Ry. Co. v. Railroad Commission of Ind., 236 U.S. 439, 448 (1915); MissouriPac. R.R. v. Porter, 273 U.S. 341, 345-6 (1927).

28. In Rice v. Bd. of Trade of Chicago, 67 Sup. Ct. 1160, 1164 (1947), the Court thus referred to $\$ 12$ of the Commodity Exchange Act (49 STAT. 1491 (1936), 7 U.S.C. \&1 (1940) et seq.): "Moreover the provision in Sec. 12 of the Act that the Secretary 'may co- 
trative construction of the federal statute so as to permit state action may $^{23}$ or may not ${ }^{30}$ have weight in determining Congressional intention.

operate with any department or agency of the Goyernment, any State . . . or politieal subdivision thereof supports the inference that Congress did not design a regulatory system which excluded state regulation not in conflict with the federal requiremcnts."

As previously referred to, the Michigan Supreme Court in upholding the Detroit OPA ordinance cited $\$ 201$ (a) of the Emergency Price Control Act authorizing the Price Administrator to utilize the services of federal, state and local agencies. People v. Sell, 310 Mich. 305, 328, 17 N.W.2d 193, 201 (1945).

29. Mintz v. Baldwin, 259 U.S. 346, 351 (1933) : "Mluch weight is to be given to the practical interpretation of the Act by the Federal Department through its acquiescence in the enforcement of state measures to suppress Bang's disease."

Although the courts in the OPA cases did not refer to this aspect of the problem, they were informed in the Administrator's brief that the Administrator had actively encouraged and welcomed state and local assistance; that there was testimony in 1944 before three separate Congressional committees revealing the extent and importance of such assistance (Mayor LaGuardia's testimony in Hearings before the Scrate Commiltec on Banking and Carrency on S. 1767, 78th Cong., 2nd Sess. 657-9 (1944); testimony of Deputy Administrator for Enforcement Emerson in 1 Hearings before the House Committee on Banking and Currcucy on H.R. 4376, 78th Cong., 2nd Sess. 155 (1944); testimony of Administrator Bowles in Hearings before the subcomnitice of the House Conmittee on Appropriations on Second Deficiency Appropriation Bill for 1944, 78th Cong., 2nd Sess. 294 (1944); and that the Act was thereafter reenacted without change in this respect. It is interesting to compare these facts with the critical comment made on the floor of the House on November 5, 1943, principally by Rep. Dirksen regarding the OPA "model ordinance" which had just come to his attention ( 89 Cosic. REc. 9254-5 (1943)). In this connection, also, some explanation may be necessary of Section 5 of the Price Control Extension Act of 1946, 60 STAT. 670-3, 50 U.S.C.A. App. $\$ 902$ (1946): "While maximum rents are in effect under this Act with respect to housing accommodations in any defense-rental area, such housing accommodations shall not be subject to rent control by any State or local government." This provision was the reaction to an amendment which passed the Senate on July 11, 1946 (92 Covc. REc 8757 (1946)). The amendment had been offered in the interim period following the temporary suspension of rent control on June 30,1946 (following a Presidential veto) and was suggested by the fact that some states and munitipalities had jumped into the breach by enactment of their own rent controls. The amendment was designed to continue such local controls in place of the federal controls to be reenacted in the extension bills, and to permit future local controls to be enacted to take the place of the federal controls. The Conference Committee, however, rejected the amendment and reasserted the previous paramount control by the federal government, in the above-quoted language of Section 5 . This was not, of course, intended to interfere with the ordinances and state laws which had been passed to supplement and assist the federal statute and regulations by adopting their identical provisions and providing additional means of eniorcement. It was designed to avoid conflict between the federal regulations and the new loeal regulations enacted after June 30, 1946.

30. In Bethlehem Steel Co. v. N.Y. State Labor Relations Board, 67 Sup. Ct. 1026 (1947), the N.Y. State Labor Relations Act, patterned after the National Labor Relations Act, was invalidated pro tanto in spite of evidence of the administrative understanding and division of labor between federal and state boards. (The Court stressed that the state policy had conflicted with the federal board's policy of refusal to designate foremen as bargaining units, though the federal policy was thereafter changed; the state and national boards had "wide discretion," governed by "somewhat different standards"; and confict could easily arise in the future.) 
Of course, a specific Congressional provision to the effect that there is no intent to prevent state measures of a specified nature is the best solvent of the difficulty, and this has sometimes been done by Congress. ${ }^{31}$

A reading of the numerous cases on "occupation of the field" will reveal the persistent judicial concern over avoidance of actual or potential conflict or inconsistency with the federal law. That being the chief concern, it is understandable that the "occupation of the field" objection has rarely been effective in the "adoption" situations- where federal and state requirements are identical. But, even here, as has been indicated, the court may act on the theory that "coincidence is as ineffective as opposition," as did the Ohio court in the Piskura case.

The issue of conflict or inconsistency is particularly pertinent once it is decided that there has been no occupation of the field by Congress. State legislation will then be permitted in the absence of conflict or inconsistency. This is the situation which came up in People v. Lervis, ${ }^{32}$ though on the state-city rather than federal-state level. At the time this case was before the Court of Appeals, the Mailman case had already been decided, hence it was already the law in New York that state adoption and enforcement of federal OPA regulations did not run afoul of the "occupation of the field" obstacle; and the fact that the penalties attaching to state violations differed from those attaching to federal violations had not been regarded (though this was not raised or discussed) as creating an improper conflict or inconsistency. It was therefore not too difficult to persuade the court that the New York City ordinance involved in the Lewis case did not create the alleged conflict or inconsistency with the state law, in spite of some differences from the state law-principally the presence of heavier penalties in the ordinance. ${ }^{33}$ The further question of whether the ordinance,

31. Securities Act of $1933 \S 18,48$ STAT. 85 (1933), 15 U.S.C. $\$ 77 \mathrm{r}(1940)$; Securities Exchange Act of $1934 \S 28$, 48 Srat. 903 (1924), 15 U.S.C. $\S 78 \mathrm{bb}$ (1940); U.S. Warehouse Act $\$ 29$, before and after amendment 39 STaT. 490 (1916), 46 STAT. 1465 (1931), 7 U.S.C. $\$ 269$ (1940). See Rice v. Santa Fe Elevator Corp., 67 Sup. Ct. 1146 (1947), involving the latter provision.

32. 295 N.Y. 42,64 N.E.2d 702 (1945).

33. That such a difference in penalties does not invalidate the ordinance is the ustal rule. See Van Buren v. Wells, 53 Ark. 368, 14 S.W. 38 .(1890); Rossberg v. State, 111 Md. 394, 74 Atl. 581 (1909) ; City of Owosso v. Michigan Central R.R., 183 Mich. 688, 150 N.W. 323 (1915); Village of Struthers v. Sokol, 108 Ohio St. 263, 140 N.E. 519 (1923); 3 McQUillin, Law of Munictpal CoRporations $\$ 924$ (2d ed. 1943); 37 AM. JUR. $\$ \$ 165-6$ (although constitutional provisions, state statutes, or common law may invalidate such a difference in penalties or may even prevent an ordinance from making the same prohibition with the same penalty. See 3 McQunLus, supra, \$\$925-32). So, too, under the concurrent power granted by the 18th Amendment it was held that state and federal prohibition laws "may vary in many particulars, including the penalties prescribed, but this is an inseparable incident of independent legislative action in distinct jurisdictions." United States v. Lanza, 260 U.S. 377, 381 (1922) ; McCormack \& Co. v. Brown, 286 U.S. 131, 144 (1932). 
if construed to omit a wilfulness standard, was inconsistent with the state law if construed to contain such a standard, was side-stepped by the court ${ }^{34}$ though there is authority that such a difference between state and federal law, ${ }^{35}$ or between city and state law ${ }^{25}$ is not a fatal conflict or inconsistency.

A problem in the scope of the incorporation of the federal provisions, containing the seeds of substantial conflict between the federal and state statutes, was suggested by, although not squarely raised in Butter \& Egg Merchants Association v. La Guardia. ${ }^{37}$ There the plaintiff, anticipating prosecutions under the New York State War Emergency Act and War Council resolution, sought an injunction to restrain enforcement of certain OPA food regulations, which he attacked as invalid. Since Section 204(d) of the Emergency Price Control Act gave exclusive jurisdiction to the Emergency Court of Appeals to consider validity of regulations, and prohibited any injunctive relief against the Act or regulations issued pursuant thereto, the court rightly ruled it had no jurisdiction. A more interesting question would have been presented if the complaint was directed not against the federal requirements but against the state requirements. If the complaint charged that the state act and War Council resolution thereunder were violative of due process under the state constitution and the 14th Amendment, because of the arbitrariness of the requirements which had been incorporated by them from the federal regulations, it would have been at least ques-

34. From the opinion it appears that the Court misunderstood the theory of the prosecution to be that both the state law and city ordinance required wilfulness, hence there was no conflict. The theory of the defense was that only the state law required wilfulness. The Court ruled that though the "local law is not in terms limited to vilful violations" the evidence showed iwilfulness and the conviction was for a wilful violation, hence defendant was in no position to challenge validity of the ordinance for lack of a wilfulness requirement. It also observed, "the omission of the word 'wilfully' is of no legal significance and does not render the local law invalid. See People v. Sampsell, 248 N.Y. 157 where we dealt with a similar difference between a State and a loeal law." People v. Lewis, 295 N.Y. 42, 50, 64 N.E.2d 702, 704 (1945). The Court may have meant that the wilfulness requirement was to be read into the ordinance.

35. In Gilbert v. MIinnesota, 254 U.S. 325, 340-1 (1920) a Minnesola anti-sedition law was upheld which punished the same acts as those punishable under the federal antisedition law but omitted the federal requirement of criminal intent.

36. In People v. Steinhardt, 215 App. Div. 724, 213 N.Y. Supp. 882 (2d Dep't 1925), aff'd, 245 N.Y. 553, 157 N.E. 854 (1927) it appeared that $\$ 2040$ of the state penal law made a misdemeanor of the wilful violation of a requirement that adequate heat be furnished to buildings, whereas no wilfulness was required under a similar provision of $\$ 225$ of the Sanitary Code of New York City. The record on appeal shows that defendant vigorously urged the invalidity of the Sanitary Code provision as "inconsistent" with the state law. The conviction was affirmed without opinion by both the Appellate Division and the Court of Appeals. Cf. Rossberg v. State, 111 1fd. 394, 74 Att. 581 (1909) where a narcotics ordinance was upheld which prohibited mere possession as well as distribution, and the State law prohibited only the latter.

37. 181 Misc. 889 , 47 N.Y.S.2d 913 (Sup. Ct. 1944). 
tionable whether the exclusive jurisdiction provisions of the Price Control Act were applicable. ${ }^{38}$ However, in view of the disruptive effect on the federal enforcement plan that might stem from opening up the possibility of court judgments in local enforcement proceedings indirectly declaring the federal regulations invalid, it may well be contended that Congress would not have acquiesced in local legislation having such an anomalous result, nor could the local legislature have had such a result in mind. In this view the local legislation would be viewed as having incorporated sub silentio, the exclusive-jurisdiction restrictions forming the very heart of the Act with which the local legislature had sought to cooperate. ${ }^{39}$

It is apparent, even from a cursory review of the cases, that the closest interweaving of primary and adoptive legislation leaves room for vexing interstitial questions. On the whole, however, objections to adoptive laws on the grounds of occupation of the field or of conflict or inconsistency, are not likely to be a serious threat to their validity. The threat would be considerably reduced of course where the substantive provisions are identical and Congress has given some indication of its desire for cooperation from local sovereignties.

\section{UnCONSTITUTIONAL VAGUENESS}

The assertion that the Detroit OPA ordinance was unconstitutionally vague and indefinite in punishing violations of changing federal regulations not set forth in the ordinance, was the basis of the dissenting opinion in People v. Sell. ${ }^{40}$ However, the fact that administrative regulations are not set forth in a statute of the same sovereignty and change from time to time, clearly does not make a statute invalidly indefinite; and there is no reason to regard the uncertainty as substantially increased by the fact that the regulations are formulated by another sovereignty. In fact, the Alabama Supreme Court has praised for its introducing a greater element of certainty into the public's obligations, an ordinance providing that any person committing "an offense prohibited by the laws of the state of Alabama" was guilty of a misclemeanor against the city ${ }^{41}$ - though this type of ordinance is not always

38. Cf. Federated Meat Corp. v. Fleming, 159 F.2d 725 (E.C.A. 1947).

39. However, the "stay" procedure enacted by Congress in 1944 to prevent certain "good faith" defendants from being penalized for alleged violations while diligently pursuing or while seeking to pursue, their administrative remedy under the Act (sce United States v. Fish, 154 F.2d 798, 800 (C.C.A. 2d 1946), cert. denied, 66 Sup. Ct. 1377 (1946)) would not be applicable to defendants under the local legislation, since the "stay" procedure could be invoked only by those who were sued under $\$ 205$ of the federal Act or $\S 37$ of the Criminal Code, 56 Stat. 31 (1942), as amended, 50 U.S.C. App. $\S 924$ (c) (Supp. 1946).

40. 310 Mich. 305, 328, 17 N.W.2d 193, 201 (1945).

41. "Such a general or reference ordinance serves two purposes: One of convenience, 
held valid.42 Some of the cases previously referred to as upholding laws against the delegation objection also uphold them against the vagueness objection. ${ }^{43}$ An important point to remember in this connection is that an enactment otherwise invalid for vagueness may be saved by the presence of a wilfulness requirement; ${ }^{44}$ for a conviction thereunder cannot be had unless defendant has been found to have known its meaning..$^{45}$

the avoidance of expense in enacting and promulgating a volume of penal ordinances in the same terms as well-known public statutes; the other is the element of certainty.

"The meaning of the brief ordinance is not in doubt. The citizen, not required to be advised upon two parallel codes of laws, can look to one, of which he is already required to take notice, and whose construction has often been well settled, to kecp himself within the law of both jurisdictions." Casteel v. City of Decatur, 215 Als. 4, 109 So. 571, 572 (1926).

42. See, e.g., the recent decision in Town of Conway v. Lee, 209 S.C. 292, 38 S.E.2d 914 (1946).

43. See, e.g., Johnson v. Elliott, 168 S.W. 968 (Tex. Civ. App. 1914); Brown v. State, 323 Mo. 138, 19 S.W.2d 12 (1929); Wright v. Worth, 83 Fla 204, 91 So. 87 (1922) ; People v. Sell, 310 Mich. 305, 17 N.W.2d 193 (1945).

44. See, e.g., United States v. Ragen, 314 U.S. 513 (1942); Screws v. United States, 325 U.S. 91 (1945).

45. Various issues deserving of brief mention have come up under the New York OPA adoption legislation. One was responsibility of an individual employer for violations by his salesmen-an issue which is of course not peculiar to this type of legislation. The only violations shown were those of defendant's salesmen. There was evidence that defendant knew of past violations by his salesmen, and had instructed them to malke up certain losses. The complaint charged that he "unlawiully" sold over cciling (rather than "wilfully," as defendant claimed was necessitated by the alleged wilfulness requirement of the state law). Defendant was fined $\$ 175$ and given a suspended sentence of 10 days. The Court of Special Sessions, Appellate Term, First Dept. affirmed on the ground that the evidence warranted the Magistrate in finding wilful violations by defendant. The Court of Appeals similarly affirmed without opinion, with a brief dissenting observation that the evidence was insufficient to sustain a conviction. Pcople v. Rosengarten, 296 N.Y. 903, 72 N.E.2d 623 (1947).

Another issue not closely related to the adoption problem was that of Magistrate Court jurisdiction over the cases under the New York legislation. People cx rel. Gross v. Adams, 296 N.Y. 604, 68 N.E.2d \&\$3 (1946) affirmed without opinion the ruling of the court below, 270 App. Div. 607, 62 N.Y.S.2d 564 (1st Dep't 1946) on the rather novel point that for offenses below the grade of misdemeanor there is a residual jurisdiction in the Magistrate's court, where no statute specifically places the jurisdiction over the particular offense in any court. Unlike the state law, the city ordinance did not designate the Magistrate's court as having jurisdiction. The decision was extremely important for effective enforcement of the ordinance, in view of the summary procedure of the Magistrate's court.

A question which may recur, however, under adoption legislation was involved in Matter of Harris Motors, 296 N.Y. 242, 72 N.E.2d 305 (1946), i.e., the necessity of reenactment of the adoptive law where there has been a hiatus or cliange in federal controls. The ordinance had provided that it was to remain in effect as long as the federal acts under authority of which the price and rationing regulations were issued should remain in effect. The Emergency Price Control Act expircd June 30, 1946, and was not 


\section{Adoptive Legislation as an Exercise of Local Police Power}

Adoptive statutes and ordinances, like all other expressions of the legislative will, must ultimately meet the legal challenges directed against their substantive validity. Issues of delegation, incorporation by reference, and the like, are in a sense ritualistic-they are concerned with the methods by which power is exercised. These issues do not front upon the final question of whether, granted validity of method, states and municipalities have the underlying power they profess to exercise over people's conduct. The answers to this question do not depend upon the form in which legislation is cast, but upon the subject matter over which power is asserted and the basic fairness of the attempted regulation. The substantive validity of the adoptive legisla. tion which lent local impetus to the enforcement of OPA is deserving of special comment, for under this legislation states and cities extended the traditional limits of local government by exercising unprecedented control over vast areas of the American economy. Precedentwise, much significance may attach to the judicial willingness to cloak this adoptive legislation in the protective folds of the police power.

Curiously enough, a threshold question is whether the police power is involved at all. The Ohio Supreme Court in City of Cleveland v. Piskura thought it was not. The basis of the court's conclusion is none too clear, but it might be spelled out as follows: the Cleveland ordinance ${ }^{40}$

revived until July 25, 1946. The alleged violation of the ordinance occurred August 5 , 1946. The defendant claimed the ordinance was ineffective for lack of reenactment after the expiration of federal controls; and attacked the trial proceedings by writ of prohibition. The writ was denied on the merits by Justice Botein, who was affirmed without opinion by the Appellate Division, First Dept., which was affirmed by the Court of Appeals on the ground that prohibition was the wrong remedy. On the merits defendant seems to have been quite wrong. Insofar as the defendant was arguing that the local law could not constitutionally have had reference to future amendments or future substitute statutes, he was raising the delegation objection which had been rejected in People v. Mailman, stpra p. 203. Insofar as he war arguing on the basis of the intent of the local law, the argument was belied by the stated purpose of the law to "cooperate with the price, rationing and rent control programs of the ... United States ..." and by the provision prohibiting charging more than the maximum price which "has been or may hereafter be prescribed by any regulation ... . issued by the office of price administration ..." There was, moreover, a special factor in this case. Even if the local law had specified that its effectiveness be dependent on an unbroken effectiveness of the federal act, this would not have impaired the effectiveness of the local law, in view of $\$ 18$ of the federal extension law, under which there was, in legal contemplation, an tubroken effectiveness of the federal controls: The 1946 Act was to take effect, with some exceptions, "as of June 30, 1946."

46. "Sec. 2207-1. Whoever, in the course of trade or business or for profit sells or in any other way transfers a commodity, rationed by any order or regulation of the Unitcd States of America, or any agency thereof, without taking in exchange for such commodity the coupons, stamps, certificates, ration checks or other ration documents, if any, required by the order or regulation in effect at the time of the sale or transfer, shall be 
did "nothing more than provide a penalty for the riolation of the federal act within the confines of the city of Cleveland"; "77 Congress had "occupied the field" by the federal Emergency Price Control Act and determined that only federal courts should have juriediction of criminal proceedings under the Act; hence, the municipal penalty and municipal jurisdiction were improper, and "no question of munticipal home rule is in anyreise involved." 48

The court did not say that, in view of the decision on occupation of the field, the question of municipal home rule is not reached; it said that the question is in no way involved. Presumably this is because the court regarded the ordinance as simply an attempt to write another sanction and another jurisdictional provision into a federal statute. But, it seems clear that municipal penalties are, and can only be, imposed for violation of municipal prolibitions. And, no penalty may be imposed for the violation of a prohibition which there is no power to enact. In other words, the ordinance could not "provide a penalty for the violation of the federal Act" without adopting the federal requirements as municipal requirements, applicable within the municipality ${ }^{49}$ -an adoption which required an exertion of its police power. ${ }^{20}$ (And

guilty of a misdemeanor and upon conviction thereof shall be punished by a fine of not more than five hundred $(\$ 500.00)$ dollars or imprisoned in the workhouse for not more than (60) days or both for such offense.

"Sec. 2207-2. Whoever sells a commodity which is the subject of a ceiling price fised by or under the authority of the United States of America at a price in excess of such ceiling price so established, shall be guilty of a misdemeanor and upon conviction thereof shall be punished by a fine of not more than five hundred $(\$ 500.00)$ dollars or imprisonment in the workhouse for not more than sixty $(60)$ days or both for each offense.

"Sec. 2207-3. Independent of the penalty prescribed for the violations of Section $2207-1$ and 2207-2, and in addition thereto, any person who is found guilty of a violation of any of the provisions of Sections 2207-1 or 2207-2 may, upon the recommendation of the commission of markets, weights and measures, be deprived of any license issued to such person by the city of Cleveland, and any person who is found suilty of a second or subsequent violation of any of said provisions shall forthwith be deprived of any license issued to such person by the city of Cleveland; provided, further, that any license revoked for such second or subsequent offense shall not be reissued during the period of the present war emergency and six months thereafter to such person or to any other person, firm, or corporation, in his behalf, or in which he may have an interest. It shall ba the duty of the commissioner of assessments and licenses to notify the enforcing agencies of the city forthwith of all licenses revoked hereunder." 1 PIKE \& FISCRER, OPA GE:ERAL DESK BoOK 6085 (1943).

47. City of Cleveland v. Piskura, 145 Ohio St. 144, 156, 60 N.E.2d 919, 924 (1945).

48. Id. at 149,60 N.E. 2d at 921 (italics added).

49. Cf. Ex Parte Siebold, 100 U.S. 371, 387-9 (1879) where a federal law punishing violations by state officials of their election duties under state was upheld, after being construed as adopting the state law requirements as federal requirements.

50. Whether regarded as the exercise of a power to meet the dangers of inflation within the city or simply a power to assist the federal government in the exercise of one of the latter's legitimate undertakings, it may properly be classified under the police 
violations of the ordinance being municipal offenses, jurisdiction of the local courts was, of course, proper.) ${ }^{51}$ In disposing of the Sell case, the Michigan Supreme Court had no difficulty in seeing the relevancy of the police power issue, devoting more than half of its opinion to an analysis of the police powers of a home-rule city in a wartime emergency and concluding that Detroit had ample power to pass the ordinance. ${ }^{52}$ In the Mailman case, the lower court, which was affirmed without opinion by the New York Court of Appeals, assumed the pertinence of the police-power issue by briefly considering and rejecting, at the close of its opinion, the due process objection under the State and Federal Constitutions. And, the New York Court of Appeals also considered this objection briefly but explicitly in the Lewis case.

In their treatment of the police power issue, the Michigan court and the lower New York court were impressed by the fact that the same price-control requirements which were, in effect, embodied in the local legislation were already applicable to the inhabitants of Detroit and New York, respectively, by virtue of the fact that the federal wartime act was the "law of the land", applicable throughout interstate and intrastate commerce. The local prohibitions became applicable to these inhabitants in addition to the federal prohibitions, but they imposed no new standard of conduct; hence, they required less exertion of police

power, which includes the broad "general welfare" authority. Even if regarded as not within the police power, a state's exercise of the power would not thereby become illegal. For, if not restricted by express or implied limitations of the State constitution or by paramount federal law, a state may exercise any power even though not specifically designated in the state constitution. See 1 Cooley, Constiturional Linirations 173-9 (8th ed. 1927).

51. Cf. Hebert v. Louisiana, 272 U.S. 312,314 (1926) rejecting the contention that the exclusive federal criminal jurisdiction provided by $\$ 256$ of the Judicinl Code was applicable to criminal proceedings for violation of a state liquor law similar to the National Prohibition Act, where the conduct involved was a violation of both laws. Miller's Executors v. Swann, 150 U.S. 132, 136 (1893): "The fact that the state statute and the mortgage refer to certain acts of Congress as prescribing the rule and measure of the rights granted by the State does not make the determination of such rights a Federal question."

52. The ordinance read as follows: "Sec. 1. It shall be unlawful for any person, firm, copartnership, association or corporation, in the course of trade or business, to wilfully and knowingly sell or in any way to transfer a commodity rationed by any order or regulation of the United States of America, or any agency thereof, without taking in exchange for such commodity the coupons, stamps, certificates, ration checks or other ration documents, if any, required by the order or regulation in effect at the time of the sale or transfer.

"Sec. 2. It shall be unlawful for any person to wilfully and knowingly sell a commodity which is the subject of a ceiling price fixed by or under the authority of the United States of America at a price in excess of such ceiling price so established.

"Sec. 3. Any person, firm, copartnership, association, or corporation violating any of the provisions of this ordinance shall, upon conviction thereof be subject to a fine not 
power to enact. ${ }^{53}$ Both courts were also influenced by the emergency character of the local legislation. As the Michigan court observed: "We have repeatedly recognized that emergencies may require the enactment of statutes or ordinances which might be held improper in normal times. Therefore, this ordinance should not be judged by the same tests as those applied to an ordinance enacted in peacetime." 54 In particular, the emergency of war had a special significance for both courts. The New York legislation was regarded as defensible in terms of a kind of "war power" of the state. 35 The Michigan court asserted the same

exceeding $\$ 500$ or imprisonment in the Detroit house of correction for a period not exceeding 90 days, or both such fine and imprisonment in the discretion of the court.

"Sec. 4. This ordinance is hereby declared to be necessary for the preservation of the public peace, health and safety and is hereby given immediate effect." Ord. No. 349-D of the city of Detroit, made effective Oct. 14, 1943.

53. Thus, in the midst of its discussion of the police-power of a home-rule city in an emergency, the Michigan Court observed: "It should be noted that the ordinznee did not create new regulations and prohibitions but merely added the city's enforeenent sanction to Federal laws and regulations which were already applicable to the city and its inhabitants during the emergency." People v. Sell, 310 Mfich. 305, 319, 17 N.W.2d 193, 197 (1945). The New York Court said: "As to section 6 of article I of the State Constitution, which provides that no person shall be deprived of life, liberty or property without due process of law, it is again to be noted that the price regulations are fixed by Federal legislation which has already been sustained by the Supreme Court of the United States in Rottenberg v. Unitcd States (321 U.S. 414) and Yokus v. Uniled States (321 U.S. 414) . . . . As to the Fourteenth Amendment to the Constitution of the United States which, among other things, provides that no State shall deprive any person of life, liberty or property without due process of law, it is sufficient to repeat that the State War Emergency Act is merely an enforcement act, since it does not and cannot change the terms or the force and effect of the act of Congress in establishing the Office of Price Administration, and granting powers for the fixing of price ceilings in restraint of inflationary commodity prices." People v. Arailman, 182 Mfisc. 870, 877, 49 N.Y.S.2d 733, 739 (N.Y. City Cts. 1944), aff'd arithout opinion, 293 N.Y. 887, 59 N.E.2d 790 (1944).

54. People v. Sell, 310 MFich. 305, 319, 17 N.W. 2d 193, 197 (1945).

55. "In considering the legislation establishing the State War Council and the resolution of the latter, adopted in pursuance thereof, it should be noted that the State has undertaken to put itself on a war basis in support of the United States and its Allies in the pending struggle against the Axis powers. Under our form of government the power to declare war is lodged exclusively in the Congress of the United States. That, however, does not prevent a State from enacting legislation and taking every step in support of national defense in time of war. That the legislation is designed as a war measure appears from the title 'War Emergency Act'. Moreover, the War Council, by Section 5 Chapter 445 Laws of 1942 , is 'created and established as a temporary state commission', presumably to lapse upon the termination of the war. The temporary character of the legislation as a war measure is further emphasized by its successive extensions for brief periods of time.

"From an examination of the legislation as a whole one cannot escape the conclusion that the State of New York is making an all-out effort to back the National Government in its effort to bring the war to a speedy and successful termination. Consequently it might reasonably be contended that the legislation should be sustained as a war measure, predicated upon the inherent powers of the State to adopt measures not in conflict with 
idea by invoking the World War I cases upholding state sedition acts similar to the federal sedition act-cases which pointed out that in time of war a state may "make the national purposes its own purposes to the extent of exerting its police power to prevent its own citizens from obstructing the accomplishment of such purposes" 66 and that "this country is one composed of many and must on occasions be animated as one and ... the constituted and constituting sovereignties must have power of cooperation against the enemies of all." ${ }^{67}$ Other authorities, too, might have been cited for the proposition. ${ }^{58}$

But, also included in the reasoning of the Michigan court is a discussion of police power which is independent of the foregoing factors peculiar to the wartime inflation emergency. The court points out that a presumption of constitutionality supports the ordinance as it would a statute; that except as limited by state constitution or statute, the police power of Detroit as a home-rule city is the of same general nature as the state's police power, and, hence, various authorities upholding the exercise of broad police power by states are applicable here; that home-rule municipalities, under the modern cases, may exercise their police power to safeguard "the general or public welfare in its most comprehensive sense" and, therefore, may concern themselves with "regulated municipal development, the security of home life, the preservation of a favorable environment in which to rear children, the protection of morals and health, the safeguarding of the economic structure upon which the public good depends, the stabilization of the use and value of property, the attraction of a desirable citizenship and fostering its permanency." " 59 The limits of the power, the court believes, are those established by the Supreme Court with respect to state police power in Nebbia v. New York. ${ }^{00}$ "There can be no doubt that upon proper occasion and by appropriate measures the state may regulate a business in any of its aspects, including the prices to be charged for the products or commodities it sells. . . . Price control, like any other form of regulation, is unconstitutional only if arbitrary, discriminatory,

those adopted by the National Government." 182 Misc. 870, 875, 49 N.Y.S.2d 733, 737 (N.Y. City Cts. 1944), aff'd without opinion, 293 N.Y. 887, 59 N.E.2d 790 (1944).

56. State v. Holm, 139 Minn. 267, 275, 166 N.W. 181, 183 (1918).

57. Gilbert v. Minnesota, 254 U.S. 325, 329 (1920).

58. See State v. McClure, 30 Del. 265, 105 Atl. 712 (1919); State v. Gordon, 138 Fla. 312, 316, 189 So. 437, 439 (1939) ; State v. Kahn, 56 Mont. 108, 116, 182 Pac. 107, 108 (1919); State v. Tachin, 92 N.J.L. 269, 106 Atl. 145 (Sup. Ct. 1919), aff'd, 93 N.J.L. 485, 108 Atl. 318 (1919), app. dismissed, 254 U.S. 662 (1920); Pcople ext rel. Doscher v. Sisson, 180 App. Div. 464, 468, 167 N. Y. S. 801, 804 (1917), aff'd, 222 N.Y. 387, 118 N.E. 789 (1918) ; Cass Township v. Dillon, 16 Ohio St. 38 (1864); 3 WILLoughay, The Constitutional Law of the United States 1574-5 (2d ed. 1929).

59. 310 Mich. $305,316,17$ N.W.2d 193, 196. The court is here quoting from its decision in Cady v. City of Detroit, 289 Mich. 499, 514, 286 N.W. 805, 810 (1939).

60. 291 U.S. 502, 537-9 (1934). 
or demonstrably irrelevant to the policy the legislature is free to adopt."61 This policy of the Nebbia case, which represents a relatively recent expansion of the state police power concept, ${ }^{62}$ is matched by an analogous expansion in the field of municipal police power. ${ }^{63}$

The New York Court of Appeals so recognized, when in the Lewis case, without reference to the emergency at all, it held: "The Constitution of the State (art. IX, $\S 12),{ }^{64}$ the City Home Rule Law $(\$ 11$,

61. Ibid.

62. The decision, which declared that "affected with a public interest" is the equivalent of "subject to the exercise of the police power" is a landmark in constitutional law. There was a time when a price-control enactment was subjected to the special test of whether the economic activity being regulated was "affected with a public interest." This was the test applied, for instance, when the United States Supreme Court decided that purported police power laws controlling the resale price of theater tickets in New York (Tyson and Bros. v. Banton, 273 U.S. 418 (1927)) or controlling the rates charged by employment agencies in New Jersey (Ribnik v. MfcBride, 277 U.S. 350 (1928)) were invalid (although even at that time Mr. Justice Stone's dissenting opinion in Ribnil: $v$. McBride, stipra, at 360 , could recite considerable authority for the proposition that regulations were within the police power "whenever any combination of circumstances seriously curtails the regulative force of competition, so that buyers or sellers are placed at such a disadvantage in the bargaining struggle that a legislature might reasonably anticipate serious consequences to the community as a whole"). The departure made by the Nebbia case is strikingly shown by the fact that it was relied upon in a subsequent New York case sustaining a theater ticket law similar to that involved in the Ty'son case (cf. Kelly-Sullivan, Inc. v. Moss, 174 Misc. 1098, 22 N.Y.S.2d 491 (Sup. Ct. 1940), off'd without opinion, 24 N.Y.S.2d 984 (1st Dept. 1940)) and in a Supreme Court ease expressly overruling the Ribnik case and upholding the Nebraska statute regulating the fees charged by employment agencies (Olsen v. Nebraska, 313 U.S. 236 (1941)). The Nebbia case was also cited, among others, in West Coast Hotel Co. v. Parrish, 300 U.S. 379 (1937), upholding a state minimum wage law for women and overruling Adlins v. Children's Hospital, 261 U.S. 525 (1923).

63. "It is now no longer questioned that the state may interiere direetly or indirectly by any of its agencies, including, of course, the municipal corporation, 'whenever the public interests demand it, and in this particular a large discretion is necessarily vested in the legislature to determine not only what the interests of the public require, but what measures are necessary for the protection of such interests.' Accordingly, the police power is sufficiently comprehensive to embrace new subjects as exigencies arise and changing conditions require. ...

"It is certain that the recent judicial decisions incline to give a more extensive scope to the police power than the earlier cases. The general welfare is expanding rapidly. In its application to urban life it is wide and varied. The last two generations have witnessed a decided change in the views of the courts relating to the construction and praetical operation of police ordinances. Greater power is freely conceded to be vested in the public authorities. Their judgment and discretion is more respected. The public welfare in its broadest sense has been adopted as the basis of construction. This position is sound, and is certain to aid materially the development of better urban conditions." 3 MrcQuilin, The Law of Municipal Corporations $\$ 942$, pp. 86, 88 (2d ed., Keamey 1943 revision).

64. N.Y. Const. Art. IX, \$12 provides:

"\$12. (Power of cities to enact local laws relating to property, affairs or government.) Every city shall have power to adopt and amend loeal laws not inconsistent with 
subd. 2) ${ }^{65}$ and the New York City Charter $(\$ 27)^{66}$ have conferred upon the City Council broad legislative power to provide by local law for the preservation and promotion of the health, safety and general welfare of its inhabitants. If such laws have substantial relation to matters over which legislative power is vested in the local legislative body of the city and are not inconsistent with laws of the State, they are valid. ... .

"There can be no doubt that such a law limposing penalties for violation of OPA regulations] is within the field of legislative power of the city as defined in the provisions of the Constitution, the City Home Rule Law and the New York City Charter unless it is inconsistent with

the constitution and laws of the state relating to its property, affairs or government. Every city shall also have the power to adopt and amend local laws not inconsistent with this constitution and laws of the state, and whether or not such local laws relate to its property, affairs or government, in respect to the following subjects: . . the government and regulation of the conduct of its inhabitants and the protection of their property, safety and health."

65. N.Y. City Home Rule Law, Art. 2, §11 provides:

" $\$ 11$. Power of cities to adopt and amend local laws.

1. Subject to the restrictions provided in this chapter, the local legislative body of a city shall have power to adopt and amend (a) local laws in relation to the property, affairs or government of the city ... Such local laws may change or supersede any provision of an act of the legislature theretofore enacted which provision does not in terms and in effect apply alike to all cities. ...

2. The local legislative body of a city shall also have power to adopt and amend local laws in relation to .... the government and regulation of the conduct of its inhabitants and the protection of their property, safety or health, whether such local laws relate to the property, affairs or government of such city or not. Such local laws, in so far as they do not relate to the property, affairs or government of the city or to other matters in relation to which the city is authorized by subdivision one to pass local laws, shall not change or supersede any act of the legislature. ...

3. In the exercise of such powers, the local legislative body of a city shall have power: .... (b) To provide for the enforcement of local laws by legal or equitable proceedings, to prescribe that violations thereof shall constitute misdemeanors and to provide for the punishment of violations thereof by civil penalty, fine, forfeiture or imprisonment, or by two or more of such punishments."

66. Sec. 27 of the New York City Charter provides: "Any enumeration of powers in this charter shall not be held to limit the legislative power of the council except as in this charter specifically provided. The council in addition to all enumerated powers shall have power to adopt local laws as to it may seem meet, applicable throughout the whole city or only to specified portions thereof, which are not inconsistent with the provisions of this charter, or with the constitution or laws of the United States or of this state, for the good rule and government of the city; for the order, protection and government of persons and property, for the preservation of the public health, comfort, peace and prosperity of the city and its inhabitants; and to effectuate the purposes and provisions of this charter or of the other laws relating to the city. The council shall have power to provide for the enforcement of local laws by legal or equitable proceedings, to prescribe that violations thereof shall constitute misdemeanors and to provide for the punishment of violations thereof by civil penalty, fine, forfeiture or imprisonment, or by two or more of such punishments." 
the laws of the State. . . " 67 That the ordinance bore a "substantial relation" to the promotion of the "general welfare" was apparently regarded by the court as almost self-evident. ${ }^{63}$

Thus, as far as the police power issue is concerned, these cases are useful precedents in the analysis of future peacetime attempts by state or local sovereignties to penalize conduct violative of federal regulations. (1) They show that, contrary to the Piskura dictum, such legislation (though in form penalizing violation of a federal regulation) is not to be regarded as merely adding another sanction against a federal offense, but as creating a local offense-hence, making relevant the inquiry of whether the local requirements established fall within the scope of one of the local sovereignty's powers e.g., police power. (2) Where the federal power involved is of such a nature that the federal requirements are applicable not only in interstate commerce but also within the local jurisdiction, the consequent fact that the local requirements establish no new standard of conduct for inhabitants of the state or municipality gives the exercise of local power less impact upon people and property, and makes it more readily sustainable as a reasonable exercise of local power. (3) Where the local enactment is grounded in the police power-and most future attempts at cooperation by "adoption" of federal regulations will be so grounded-the Lewis decision in par-

67. People v. Lewis, 295 N.Y. 42, 49-50, 64 N.E.2d 702, 703 (1945).

68. The court did indicate its feeling on the point when it observed in discussing the issue of conflict with the state law, Id. at 51, 64 N.E.2d at 704: "The local law supplements the State law by providing heavier penalties for black-market transactions in New York City of the gravest consequence to the property, safety and health of its crowded population, dependent upon thousands of small storekeepers from whom the daily necessities of life must be purchased. The situation justificd stern enforcement to avoid many evils and consequent hardship, or at least the local Legislature could so decide."

The local legislative judgment that combating inflation more effectively would redound to the general welfare of the city's inhabitants and that a local enforcement program was reasonably adapted to this objective, is, of course, readily defensible as a non-arbitrary judgment. MIuch of the creeping increase in the cost of living while price controls were in effect was due to the inadequate number of enforcement investigators available to the Office of Price Administration-a number which would probably always be inadequate, since policing of the daily transactions of $130,000,000$ people in every city, town, and hamlet of the nation cannot be accomplished with complete efiectiveness by the use of federal manpower alone. Even with an extensive and judicious use of feld offices, a law of diminishing returns in efficiency sets in, as more and more time goes into "coordination", inter-regional and intra-regional reports, etc. Enforcement stafis of states and municipalities, on the other hand, operate as a more compact unit, they are much closer to the source of the danger, they can in many cases readily adapt existing enforcement facilities to the new functions, and they can make use of local (usually swifter) court procedures. The importance to the federal OPA program in New York City, of the New York State War Emergency Act and War Council Resolution thereunder, graphically appears from the testimony of Mfayor LaGuardia on April 17, 1944, before the Senate Committee considering renewal of the federal Act in 1944 (Hcarings before Committee on Banking and Currency on S. 1764, 78th Cong., 2nd Sess. 658-9 (1944)); 
ticular, and the Sell case as well, is a reminder that the modern police power cases make unlikely an invalidation of the legislation (on the ground that it exceeds the legitimate scope of police power) where it is reasonably related to a legitimate objective. And, validation becomes the more probable when it is remembered that few examples of such future legislation will attempt to encompass as comprehensive a field of economic activity as the price, rent, and rationing controls involved in the instant cases.

and more impressive still is the following tabular analysis of prosecutions under the New York state and city legislation (obtained from the office of Chief Magistrate Bromberger) :

Number of Cases Under N.Y. State War Emergency Act (as originally enacted and as later incorporated into General Business Law in 1946) and Under N. Y. City Ordinances Enacted in July, 1945

Courts

Municipal Term, Manhattan

Other Manhattan Courts

Municipal Term, Bronx

Other Bronx Courts

Municipal Term, Brooklyn

Other Brooklyn Courts

Queens Courts

Richmond (Staten Island) Courts

${ }^{\text {aWar Emergency Court (Queens) }}$

'War Emergency Court (Manhattàn, Brooklyn and Bronx)

'War Emergency Court (Manhattan, Brooklyn, Bronx and Queens)

'War Emergency Separate Courts: Manhattan

Bronx

Brooklyn

Queens

Richmond (Staten Island)

Total 26, 1943

Welations of the War Emergency Act were first separately recorded as such commenclng May

2.War Emergency Court for the Borough of Queens established October 26, 1944; abolished December 7, 1944.

bWar Emergency Court for the Boroughs of Manhattan, Brooklyn and the Bronx cstablished Nov. 13, 1944; jurisdiction of Municipal Term Courts cancelled and rescinded effective at the close of business on November 10,1944

$c$ War Emergeney Court for the Boroughs of Mankattan, Brooklyn and the Bront enlarged to include the Borough of Queens on December 11 , 1944 .

dWar Emergency Court sessions ordered to be held in the separate boroughs of Manhattan. Brooklyn, Bronx and Queens (April 23, 1945); Staten Island Court inaugurated a separate docket for War Emergency cases July 30, 1945, prior to which time all such cases were recorded in the general docket of the Central Court.

After July, 1945, the great majority of cases were brought under the ordinances rather than the state law because they carried heavier penalties and were believed to be more clearly free of any requirement that wilfulness be shown than was the state law. The division of labor among the city officials was to have the Sheriff's office work on wholesaler violations and the Department of Markets on retailer violations. The prosecutions were handled by the Corporation Counsel's office, often with assistance from OPA personnel. Numerous cases under the New York legislation were handled wholly by OPA personnel on the theory that any citizen of New York can file and prosecute a complaint for offenses against the state or city. 